\title{
The Impact of the Ongoing Pandemic on Digital Finance Transactions: An Empirical analysis
}

\author{
Khushbu Agarwal, Nidhi Nalwaya \\ Pacific Institute of Management, Faculty of Management, Pacific University, Udaipur, India \\ Faculty of Commerce, Parul University, Vadodara, India \\ khushbu.agarwal6@gmail.com
}

\begin{abstract}
The ongoing pandemic has resulted in a disruption of the life of all citizens and impacted all the spheres, more so the financial system because the Pandemic and its aftermath has shut all economic activity except those which as per the government directives are considered the most essential. This has deeply impacted private consumption, external trade as well as investment in the economy. Accordingly, both in retail stores and e-commerce orders, a common strand is that many of the consumers are now paying bills via digital payment mechanisms and taking contactless delivery of goods wherever possible. "Digital financial transaction systems, e-wallets and apps, online transactions using e-banking, usage of Plastic money (Debit and Credit Cards), etc. have recorded a substantial increase in demand during the crisis". The objective of the present paper is to examine and analyze the digital finance transactions in selected cities during the ongoing pandemic.
\end{abstract}

Keywords: Pandemic, Digital payments platforms, Cashless Economy, Digital Finance Services.

\section{Introduction}

The recent ongoing lethal pandemic and its uncertain aftermath have meant that "most factories, markets, shops and places of worship were closed and are now partially operational, most public transports were suspended and construction work has been put on a pause, as most people stay home and practice social distancing". The pandemic and its subsequent aftermath and partial opening have impacted many sectors including Apparel and textiles, Auto and Auto Components, Aviation, Building and Construction, Petrochem and Chemicals, Financial Services, Education, MSME, Transport and Logistics et al. The Pandemic has led to, stay at home, work from home and social distancing protocols thus making the financial transactions ecosystem prone to a lot of hurdles in the given context, when consumers are wary to venture out of their homes- it has been the digital payment platforms and other internet-based services that have given respite to the consumers.

Exposition of Digital Finance Transactions - Internet Banking and Apps: Most Financial services providers in the country offer a "wide range of services and their products through Digital platforms (internet).

$>$ Online Fund Transfer: Transfer funds between accounts, even if they are in different branches or cities. Customers can also transfer funds to any person having an account with the same bank anytime, anywhere, using third party funds transfer option.

$>$ Bill Payment Service: Banks Bill Payment is the easiest way to manage bills. An account holder can pay their regular monthly bills i.e. telephone, electricity, mobile phone, insurance, etc. at any time, anywhere for free.

$>$ Trading Account: Demat is a commonly used abbreviation of Dematerialization, which is a process whereby securities like shares, debentures are converted from the material (paper documents) into electronic data and stored in the computer of an electronic Depository.

$>$ Debit Card \& Credit Card: Debit cards allow bank customers to spend money that they have by drawing on funds that they deposited with the card provider. Credit cards allow consumers to borrow money from the card issuer up to a certain limit to purchase items or withdraw cash.

$>$ Mobile Banking: Mobile banking is a service provided by a bank or other financial institution that allows its customers to conduct financial transactions remotely using a mobile device such as a mobile phone or tablet. It uses software, usually called an app, provided by the financial institution for the purpose". 


\section{Review of Literature}

Board (2021) mentioned that compared to developed nations, quite less number of Indian female is availing banking services independently which can be due to lack of awareness or dependency. According to Meghani (2017), internet banking is an improvement over PC banking and it is done over a highly accessible public network. It is accessible to anyone using the Internet not just the bank's customers". Mihir \& Chavda (2014) pointed out that internet banking adoption become popular in the year 2000 and started peaking up from the year 2012 onwards". Umrez (2016) described that most customers who have adopted internet banking services believe that it has got a lot of advantages while on the other side some believe that because of security and privacy issues innovative banking has disadvantages". Chavan (2013) discusses some challenges in an emerging economy. Paper concluded that one of the benefits that banks experience when using ebanking is increased customer satisfaction. The purpose of the study of Pekka (2008) is to further the understanding of innovation resistance by dividing internet banking non-adopters into three groups based on their intentions to use the innovation. Thereafter, the aim is to identify how the resistance differs in these customer groups".

Significance of Study: A survey by KPMG "Potential impact on Covid-19 on the Indian Economy emphasizes that this crisis will give a real push to Digital and will have extensive as well as intensive implications for moving fast forward towards a physical model (Brick and mortar and Digital), the impact will be on the way companies do business and employees work - the B2B, B2C, B2G services, e-commerce, e-governance, etc. Digital financial companies have also risen to the challenge, setting up shops in more expedient places to allow people to sign up and use their money as they wish. Paytm, Mobikwik, BHIM UPI, Amazon pay, etc have seen a huge surge in transactions. According to a report by Statista, in the context of digital platforms usage for financial transactions during Covid -19 more than 33 percent said they used digital payments more than before, while nine percent made online payments exclusively. This brings to for the issue of financial inclusion which is crucial as well as critical people who have access to cards and operational bank accounts are much better prepared for a crisis like a Pandemic through Direct Benefit Transfers etc than those marginalized people whose money is all in cash, primarily in the form of the currency".

\section{Research methodology:}

Statement of the Problem: The present paper is undertaken to analyze the impact of the Pandemic on Digital Finance transactions in selected cities of Vadodara, Indore and Jodhpur.

Objectives of the Study: Digital Banking offers a set of benefits as well as challenges to both its customers and organizations. The study has been undertaken to determine:

- To study the frequency of bank branch visits before and during the pandemic.

- To analyze the level of knowledge regarding Internet Banking facilities among respondents.

- To study the impact of the pandemic on the usage of Digital Finance services by analyzing the frequency of the usage of different digital financial services before and during the pandemic.

\section{Data collection:}

Primary as well as secondary data is referred for the study. Primary data was collected with the help of a questionnaire and secondary data was collected from various sources such as journals, books, websites, reports, etc.

\section{Sampling:}

A sample of 360 customers was drawn by using the convenience sampling technique. The questionnaire was mailed to all the respondents and 246 filled questionnaires were received, the response rate was 68.3 percent.

Sampling Technique: convenience sampling technique

Sample size: 246 customers of three major cities i.e. Indore, Vadodara \& Jodhpur. 


\section{Hypothesis testing:}

The Chi-Square test of independence is employed to analyze the collected data to determine whether the frequency of using digital banking services is independent or dependent on the Pandemic.

Limitations of the Study: The study was conducted under certain limitations such as, that the sample has been taken from three selected cities in India and the respondents have been selected through convenience sampling. The data has been collected through a structured online questionnaire; it may restrict the opinion of the customers.

\section{Data Analysis}

The survey has been conducted in three major cities. A Questionnaire was used as the research instrument, which contained 2 sections: Demographic profile of customers and frequency of using major aspects of Digital finance transactions (internet banking).

\begin{tabular}{llll}
\hline Demographics & Range & No. of Respondents & \% \\
\hline Age & $18-25$ & 179 & 72.76 \\
& $26-35$ & 39 & 15.85 \\
& $36-45$ & 18 & 7.32 \\
Gender & $>45$ & 10 & 4.07 \\
Education & Male & 162 & 65.85 \\
& Female & 84 & 34.15 \\
& SSC & 8 & 3.25 \\
& HSC & 8 & 3.25 \\
Occupation & Graduate & 30 & 12.20 \\
& PG & 193 & 78.46 \\
& Ph D & 7 & 2.85 \\
Income & Business & 29 & 34.96 \\
& Service & 86 & 19.11 \\
& Professional & 47 & 0.41 \\
& Housewife & 1 & 33.74 \\
City & Student & 83 & \\
& 5000-15000 & 103 & 41.87 \\
& 15001-25000 & 57 & 23.17 \\
& 25001-35000 & 37 & 15.04 \\
& 35001 or above & 49 & 19.92 \\
& Vadodara & 72 & 29.27 \\
& Indore & 108 & 43.90 \\
& Jodhpur & 66 & 26.83 \\
\hline
\end{tabular}

Five Points Multiple Choice Grid has been Used Ranging

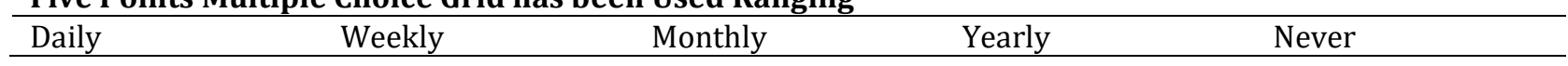

A sample of 360 customers was drawn by using the convenience sampling technique. The questionnaire was mailed to all the respondents and 246 filled questionnaires were received, the response rate was 68.3 percent. Chi-Square test of independence is employed to analyze the collected data to determine whether the frequency of using digital banking services is independent or dependent of the Pandemic with using the following equation. 
Table 1: Data Analysis

\begin{tabular}{|c|c|c|c|}
\hline Questions & Options & No. of Respondents & $\%$ \\
\hline Q1) Do you have your & Yes & 246 & 100.00 \\
\hline bank account? & No & 0 & 0.00 \\
\hline Before & 1 to 4 times & 170 & 69.11 \\
\hline pandemic, & 5 to 8 times & 28 & 11.38 \\
\hline frequently were you & 9 to 12 times & 8 & 3.25 \\
\hline visiting your bank & More than 12 times & 5 & 2.03 \\
\hline branch per month? & Never & 35 & 14.23 \\
\hline During & 1 to 4 times & 47 & 19.11 \\
\hline pandemic, & 5 to 8 times & 46 & 18.70 \\
\hline frequently do you visit & 9 to 12 times & 12 & 4.88 \\
\hline your bank branch per & More than 12 times & 10 & 4.07 \\
\hline month? & Never & 131 & 53.25 \\
\hline Q4) How & Partial Information & 54 & 21.95 \\
\hline knowledge do you have & Just known & 19 & 7.72 \\
\hline about Internet/Online & Unknown & 1 & 0.41 \\
\hline Banking Services? & Well known & 172 & 69.92 \\
\hline $\begin{array}{l}\text { Q4) Are you associated } \\
\text { with Internet Banking }\end{array}$ & Yes & 211 & 85.77 \\
\hline $\begin{array}{l}\text { Services provided by } \\
\text { your bank? }\end{array}$ & No & 35 & 14.23 \\
\hline
\end{tabular}

Which Internet Banking Services you were Using Before/During the Pandemic?

\begin{tabular}{|c|c|c|c|c|c|c|}
\hline Statements & Situation & Daily & Weekly & Monthly & Yearly & Never \\
\hline Payment & Pre Pandemic & 23 & 30 & 97 & 23 & 38 \\
\hline bills/fees/taxes & During Pandemic & 33 & 62 & 78 & 11 & 27 \\
\hline \multirow[t]{2}{*}{ Balance inquiry } & Pre Pandemic & 25 & 74 & 65 & 11 & 36 \\
\hline & During Pandemic & 50 & 85 & 48 & 4 & 24 \\
\hline Fund transfers/ & Pre Pandemic & 15 & 34 & 78 & 21 & 63 \\
\hline RTGS/ NEFT & During Pandemic & 40 & 50 & 63 & 15 & 43 \\
\hline \multirow[t]{2}{*}{$\begin{array}{l}\text { E-wallets and } \\
\text { apps }\end{array}$} & Pre Pandemic & 25 & 65 & 36 & 15 & 70 \\
\hline & During Pandemic & 50 & 72 & 30 & 10 & 49 \\
\hline \multirow[t]{2}{*}{ Debit card (ATM) } & Pre Pandemic & 46 & 89 & 45 & 10 & 21 \\
\hline & During Pandemic & 68 & 98 & 35 & 6 & 4 \\
\hline \multirow{2}{*}{$\begin{array}{l}\text { Credit card } \\
\text { ( ATM) }\end{array}$} & Pre Pandemic & 15 & 30 & 40 & 10 & 116 \\
\hline & $\begin{array}{l}\text { During } \\
\text { Pandemic }\end{array}$ & 32 & 45 & 24 & 7 & 103 \\
\hline \multirow{4}{*}{$\begin{array}{l}\text { Retrieving bank } \\
\text { statements } \\
\text { Email/text alerts }\end{array}$} & Pre Pandemic & 11 & 36 & 66 & 32 & 66 \\
\hline & During Pandemic & 29 & 51 & 49 & 22 & 60 \\
\hline & Pre Pandemic & 59 & 50 & 43 & 21 & 38 \\
\hline & During Pandemic & 82 & 64 & 33 & 11 & 21 \\
\hline \multirow{2}{*}{$\begin{array}{l}\text { Trading /Demat } \\
\text { Account }\end{array}$} & Pre Pandemic & 21 & 23 & 36 & 16 & 115 \\
\hline & During Pandemic & 43 & 36 & 26 & 10 & 96 \\
\hline
\end{tabular}


If no, then how do you prefer to adopt Internet/Online Banking Services?

\begin{tabular}{|l|l|l|l|l|l|}
\hline & $\begin{array}{l}\text { Within } \\
\text { a month }\end{array}$ & $\begin{array}{l}\text { Within a } \\
\text { year }\end{array}$ & $\begin{array}{l}\text { May be in } \\
\text { future }\end{array}$ & Never & Can't say \\
\hline Pre Pandemic & 22 & 7 & 3 & 3 & 211 \\
\hline During Pandemic & 12 & 15 & 7 & 1 & 211 \\
\hline
\end{tabular}

\section{Formulation of Hypotheses:}

H1: Frequency of online payment of bills/fees/taxes is not independent of Pandemic.

H2: Frequency of online balance inquiry is not independent of the pandemic.

H3: Frequency of online fund transfers/ RTGS/ NEFT is not independent of the pandemic.

H4: Frequency of using E-wallets and apps is not independent of the pandemic.

H5: Frequency of using a Debit card (ATM) is not independent of the pandemic.

H6: Frequency of using Credit Card is not independent of the pandemic.

H7: Frequency of Retrieving bank statements is not independent of the pandemic.

H8: Frequency of using Email/text alerts is not independent of the pandemic.

H9: Frequency of Trading /Demat Account is not independent of the pandemic".

Table 2: Application of Chi-Square Test

\begin{tabular}{llll}
\hline Criteria & $\begin{array}{l}\text { Chi-Square } \\
\text { Calculated Value }\end{array}$ & $\begin{array}{l}\text { Chi-Square } \\
\text { Critical Value }\end{array}$ & Decision \\
\hline Online payment of bills/fees/taxes & 21.08 & 13.28 & H1 is accepted \\
Online balance inquiry & 17.32 & 13.28 & H2 is accepted \\
Online fund transfers/ RTGS/ NEFT & 20.78 & 13.28 & H3 is accepted \\
E-wallets and apps & 13.94 & 13.28 & H4 is accepted \\
Debit card (ATM) & 18.49 & 13.28 & H5 is accepted \\
Credit Card & 14.45 & 13.28 & H6 is accepted \\
Retrieving bank statements & 15.34 & 13.28 & H7 is accepted \\
Email/text alerts & 14.81 & 13.28 & H8 is accepted \\
Trading /Demat Account & 15.14 & 13.28 & H9 is accepted \\
\hline
\end{tabular}

\section{Findings}

- There is a decrease in the number of visits to the bank branch during the ongoing pandemic.

- Out of 246 respondents, $70 \%$ are well knowledgeable about internet banking services, whereby, 22\% of respondents have partial knowledge for the same.

- Out of 246 respondents, 211 are associated with any of the internet banking facilities, whereby 35 respondents are still not associated with any online banking services.

- In the end by applying the chi-square test of independence, we found that "there is an increase in the usage of internet banking services after the pandemic. That means that usage frequency of online banking services is significantly associated with the pandemic situation".

\section{Conclusion and Recommendations}

The results can be interpreted that there is an impact seen on the frequency of using different internet banking services as the result of the ongoing pandemic. Most of the respondents had working knowledge about Digital finance transactions/online banking services, whereas some respondents still only have partial knowledge about the same. Some respondents who are not associated with any of the online banking facilities also have a positive view to get associated with the same within a shorter period of time. Internet banking services are providing more benefits than traditional banking channels. As the customers have knowledge about the internet and they are keen to adopt internet banking in the future, it is the responsibility of the 
bankers to create awareness about Digital Finance Transactions/ internet banking and to provide some training to the customers to encourage them to adopt and adapt.

The study concludes that pandemic attacks and the resultant lockdown have a significant impact on digital transactions and it is observed that usage of digital banking services is greatly affected due to the pandemic lockdown.

\section{Future implications of the study}

The COVID-19 event may yet test the resilience of the global financial system. Economic forecasts have been revised upwards, and buoyant asset valuations could be tested by a further rise in government bond yields. At the same time, uncertainty remains high against the backdrop of uneven vaccination progress and the continuation of containment measures. Identifying systemic vulnerabilities early on remains a priority. . Preserving financial stability is a necessary precondition for ensuring the smooth flow of finance to the real economy.

COVID-19 has reinforced the need to promote resilience amidst a rapid technological change in the economy and global financial system. The rapid use and adaptation of new technology have helped firms to operate effectively in the new environment. At the same time, they have put the spotlight on the need to ensure operational resilience in an environment of greater reliance on outsourcing and third-party service providers, including on a cross-border basis. More generally, the boost that COVID-19 seems to have given to digital financial services, in particular, various forms of digital payments reinforces the need to ensure that regulatory frameworks and approaches provide a solid basis for harnessing the benefits of such innovation while containing their risks.

\section{References}

Board, F. S. (2021). Lessons Learnt from the COVID-19 Pandemic from a Financial Stability Perspective. Financial Stability Board.

Chavan, J. (2013). INTERNET BANKING- BENEFITS AND CHALLENGES IN AN EMERGING ECONOMY. IMPACT: International Journal of Research in Business Management, 19-26.

http://www.jrfinancial.in/blog/impact-Pandemic-rs-500-rs-1000-note-various-sectors-economy/

http://qz.com/843872/indias-rupee-Pandemic-could-spark-a-new-digital-economy-in-the-cash-reliantcountry/ (Yogesh K Dwivedi, Swansea University; Kuttimani Tamilmani, Swansea University, and Nripendra Rana, Swansea University)

https://theconversation.com/modis-bank-note-ban-has-inflicted-pointless-suffering-on-indias-poorest69157

http://www.business-standard.com/article/finance/7-account-holders-in-india-use-net-banking-study111072000193_1.html

Mihir B. \& Chavda, D. A. (2014). Innovative banking products: Win-Win situation forCustomers and Banks. International Journal of Commerce, Business and Management (ICBM), 824-829.

Meghani, D. A. (2017). The Impact of Demonetization on the frequency of using Internet Banking Services with reference to selected cities of Gujarat. Pacific Business Review, 64-72.

Pekka, L, S. S. (2008). Consumer resistance to Internet banking: Postponers, opponents and rejectors. International Journal of Bank Marketing, 440-455.

Umrez, M. R. (2016). Customer Resistance towards Internet Banking Among the Literates: An Empirical Study with Reference To Rayalaseema Region. Imperial Journal of Interdisciplinary Research. 